\title{
Biology and Management of Creeping Beggarweed (Desmodium incanum) in Warm-Season Turf ${ }^{1}$
}

\author{
Grantly Ricketts and Chris Marble²
}

\section{Introduction}

Creeping beggarweed is a common perennial broadleaf weed in Florida landscapes, home gardens, pastures, and other agricultural production systems. This article is written for green industry professionals and others to help aid in the identification and management of creeping beggarweed in landscape turf and planting beds.

\section{Species Description}

\section{Family}

Fabaceae

\section{Other Common Names}

Kaimi clover, Spanish clover, Spanish tick-trefoil, hitch hikers, zarzabacoa comun, and sticky weed.

\section{Life Span}

Creeping beggarweed is a broadleaf perennial weed that reproduces by seeds and stolons; it may also spread by fragments of stems or broken pieces of its taproot.

\section{Habitat}

Creeping beggarweed is found in pastures, residential and commercial landscapes, and open natural areas. It is most common in full-sun, dry areas because it does not grow well in areas that are wet or poorly drained for an extended period.

\section{Distribution}

Creeping beggarweed is native to Central and South America but is now found throughout Florida and in other southern states such as Georgia, and into south Texas. It is also found in the West Indies, tropical regions of Africa, and other tropical areas throughout the world (Green et al. 2008; USDA-NRCS 2020).

\section{Growth Habit}

Creeping beggarweed often grows in a prostrate manner (along the ground), especially when found in turf that is mowed, but can also have an upright, or erect, growth habit (Figure 1). Creeping beggarweed actively grows throughout the summer in central and north Florida but may grow throughout the year in south Florida.

1. This document is ENH1327, one of a series of the Environmental Horticulture Department, UF/IFAS Extension. Original publication date December 2020. Visit the EDIS website at https://edis.ifas.ufl.edu for the currently supported version of this publication.

2. Grantly Ricketts, commercial horticulture Extension agent I, UF/IFAS Extension Osceola County; and Chris Marble, assistant professor, Environmental Horticulture Department, UF/IFAS Mid-Florida Research and Education Center; UF/IFAS Extension, Gainesville, FL 32611.

The use of trade names in this publication is solely for the purpose of providing specific information. UF/IFAS does not guarantee or warranty the products named, and references to them in this publication do not signify our approval to the exclusion of other products of suitable composition. All chemicals should be used in accordance with directions on the manufacturer's label. Use pesticides safely. Read and follow directions on the manufacturer's label.

The Institute of Food and Agricultural Sciences (IFAS) is an Equal Opportunity Institution authorized to provide research, educational information and other services

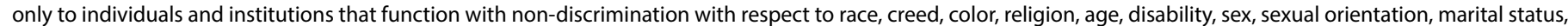

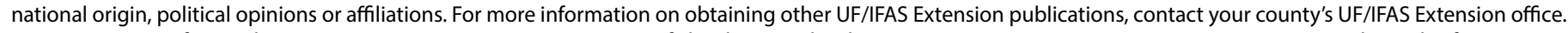
U.S. Department of Agriculture, UF/IFAS Extension Service, University of Florida, IFAS, Florida A \& M University Cooperative Extension Program, and Boards of County Commissioners Cooperating. Nick T. Place, dean for UF/IFAS Extension. 


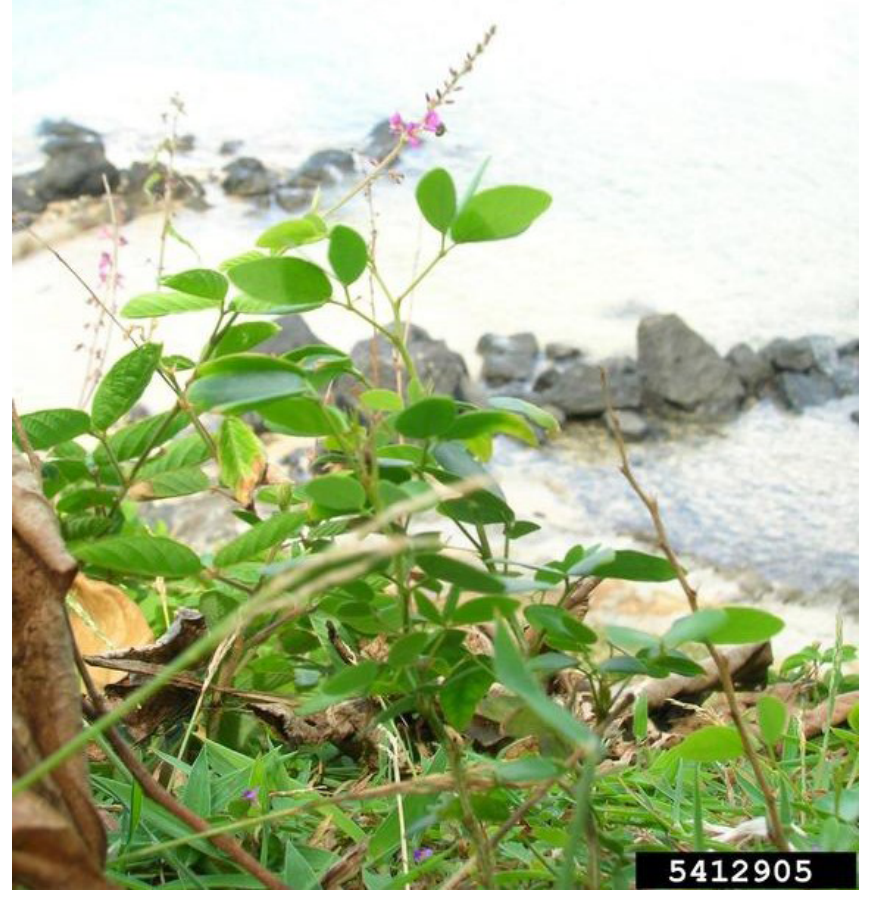

Figure 1. Upright growth habit of creeping beggarweed. Credits: Forest and Kim Starr, Starr Environmental, Bugwood.org

\section{Seedling}

Creeping beggarweed is propagated by seeds and from vegetative parts. The seedling has a high vigor, and vegetative spread is very rapid.

\section{Shoot}

Leaves are hairy, alternate, and trifoliate (three leaflets). The petioles can range from 0.25 to over 2 inches in length. Each petiole has three leaflets that are round at the base and taper to a point. The upper surface of the leaflets is dark green, while the underside is gray to light green. The leaflets have short, straight hair on the upper surface. The leaves vary in size; leaves on the upper branches are usually larger than the those on the lower branches. The stem is covered in hairs that press closely to it as the plant matures (Acevedo-Rodríguez 2005). As the plant ages, the stems can become very woody, which can make management more difficult.

\section{Roots}

Creeping beggarweed has a deep taproot system that is well branched and has the capacity to form roots from nodes along the stolon (Figure 2).

\section{Inflorescence}

In tropical areas, the plant can flower year-round, but it will only flower in the summer in subtropical and temperate regions. The flower is very small and pink to purple in color, resembling that of a pea (Figure 3).

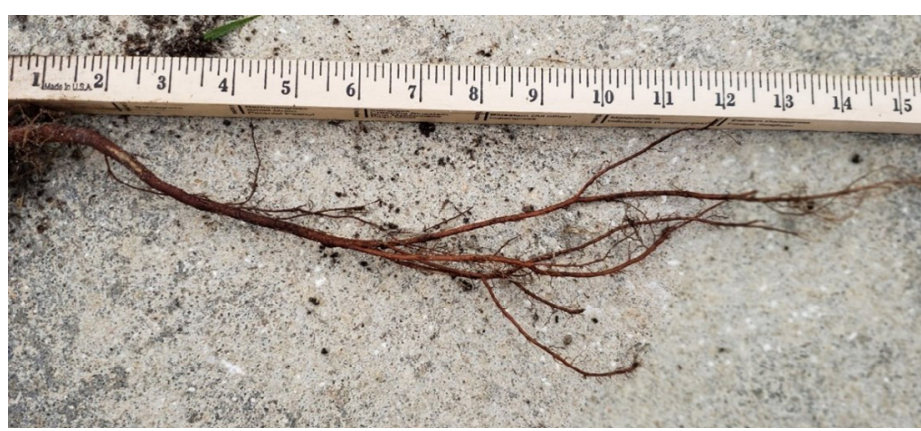

Figure 2. Example of creeping beggarweed taproot.

Credits: Grantly Ricketts, UF/IFAS

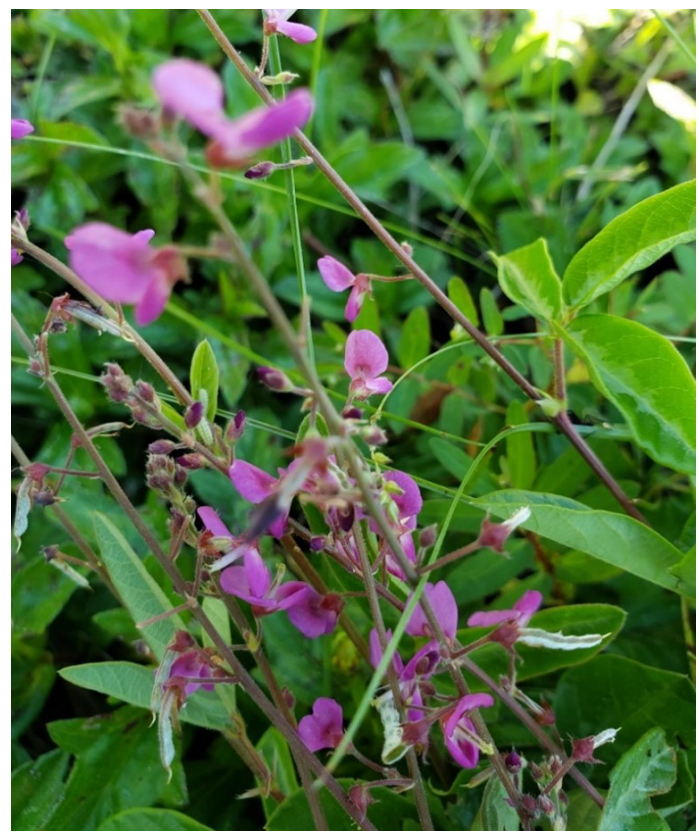

Figure 3. Example of creeping beggarweed flower. Credits: Grantly Ricketts, UF/IFAS

\section{Fruit and Seeds}

The plant produces seeds enclosed in seed pods that are divided into segments. The seed pods open when ripe, exposing seeds, which easily attach to clothes and animal fur. Seeds are 2.5-3.5 mm long, oblong elliptical in shape, and light brown in color (Figure 4) (Acevedo-Rodríguez 2005).

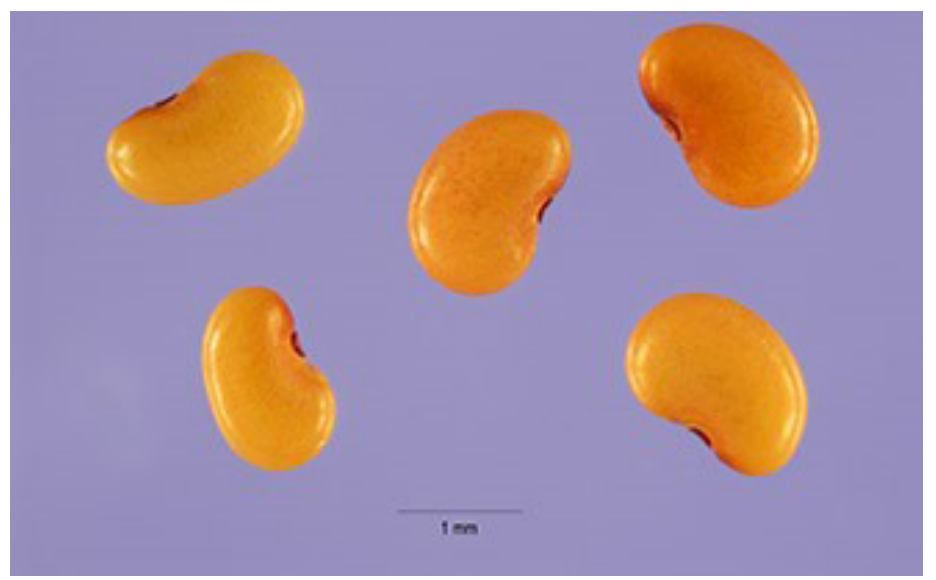

Figure 4. Example of creeping beggarweed seeds. Credits: Steve Hurst, USDA-NRCS Plants Database 


\section{Similar Species}

Creeping beggarweed (Desmodium incanum) is similar in appearance to greenleaf desmodium (Desmodium intortum), Florida beggarweed (Desmodium tortuosum) and carpon desmodium (Desmodium heterocarpon). These species can be distinguished by the following characteristics:

Desmodium intortum (greenleaf desmodium) is usually a prostrate plant less than 3.5 feet $(1 \mathrm{~m}$ ) tall (Younge, Plucknett, and Rotar 1964). Its leaves are uniformly green or sometimes have some small reddish-brown markings on their upper surfaces. Leaflets are egg-shaped, flowers are purplish-pink, and pods hang on upper and lower edges (Figure 5).

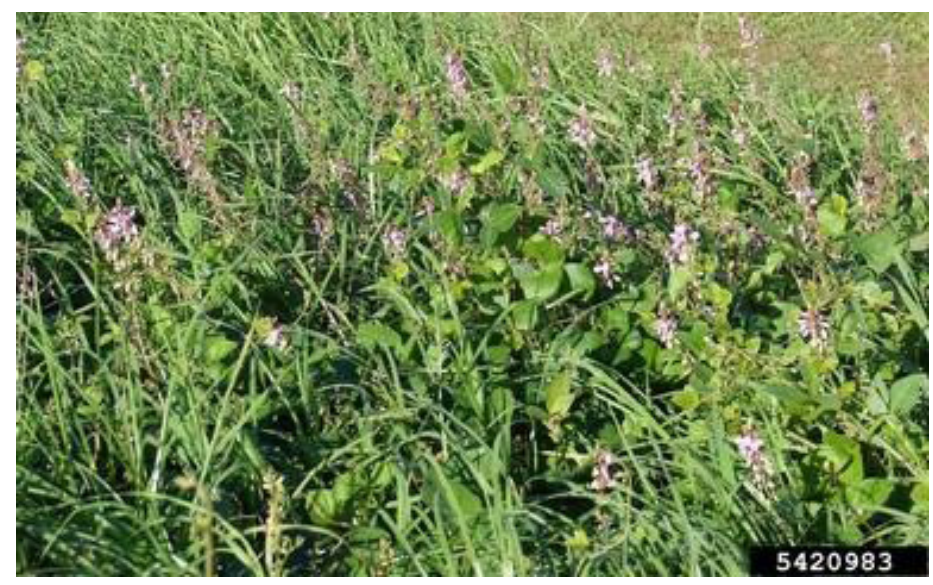

Figure 5. Greenleaf desmodium.

Credits: Forest and Kim Starr, Starr Environmental, Bugwood.org

Desmodium tortuosum (Florida beggarweed) is an upright shrubby plant growing up to 6.5 feet tall. Its leaves are uniformly green or sometimes have some small reddishbrown markings on their upper surfaces. The leaflets are hairy (pubescent) on both surfaces and have a narrow oval shape, tapering at the end. Fruit segments are rectangular in shape, and the pod is round and twisted with 2 to 6 segments. Flowers may be yellowish or pinkish in color (Younge, Plucknett, and Rotar 1964) (Figure 6).

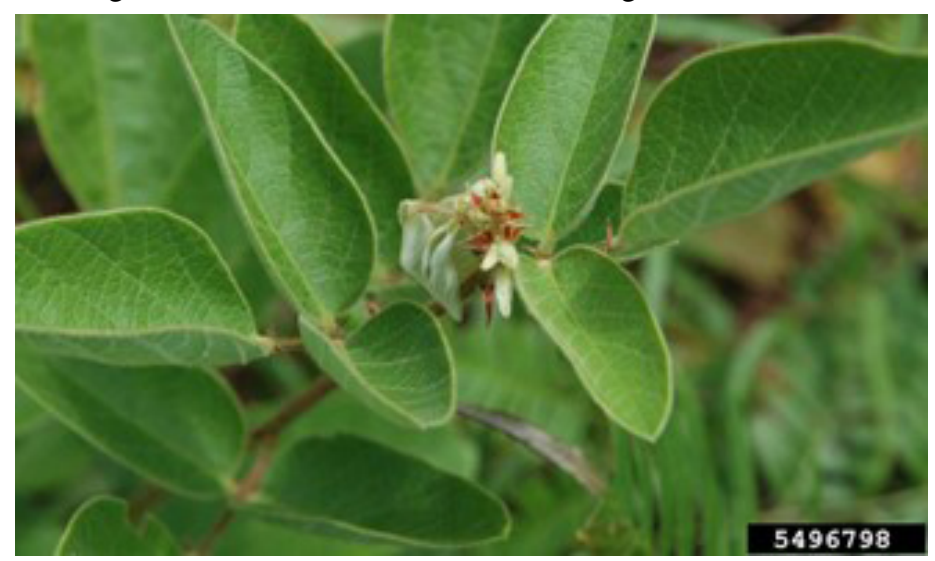

Figure 6. Florida beggarweed. Note the yellowish flower color. Credits: Katherine Russell, Bugwood.org
Desmodium heterocarpon (carpon desmodium) is a creeping to ascending plant that may be more than 40 inches long (Vendramini and Kretschmer 2016). The leaves have pale green or yellowish-green central markings on their upper surfaces. The leaflets often have rounded tips, and their upper surfaces are hairless, while the undersurface is sparsely hairy. The flower is light purple in color (Figure 7).

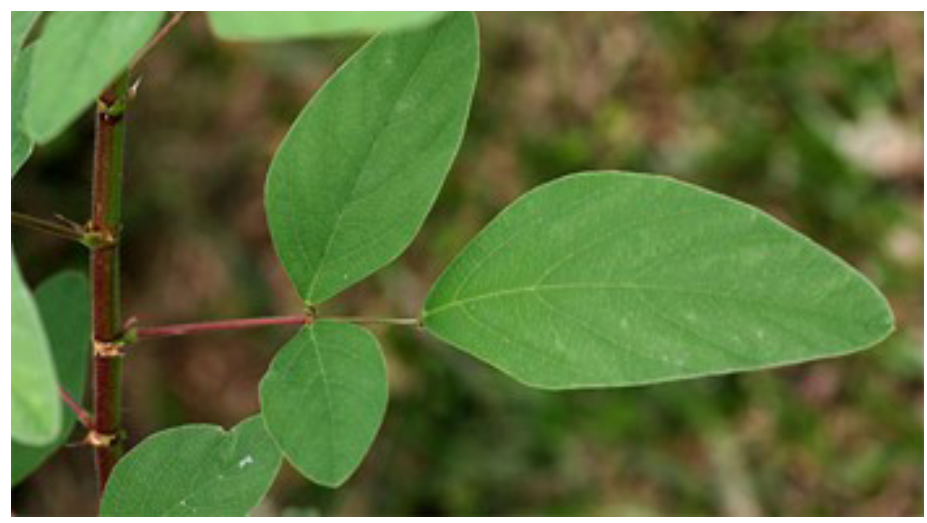

Figure 7. Desmodium heterocarpon. Note the acute leaf tip. Credits: Gregory McDonald, UF/IFAS

\section{Plant Biology}

Creeping beggarweed is a perennial herbaceous plant that grows up to 2 feet or more at maturity (Figure 8). The plant is commonly pollinated by bees and other pollinators but is also self-fertilized (does not require a pollinator) (Etcheverry et al. 2010). Reproduction is predominantly through seed. The sticky characteristics of the seedpods allow the seeds to easily adhere to clothing and fur and be spread by people or animals. Seed can also be spread by wind or water (Mori and Brown 1998). In tropical areas, creeping beggarweed can flower and set seed year-round, but seed production is usually limited to the summer months (April through November) in central or northern Florida.

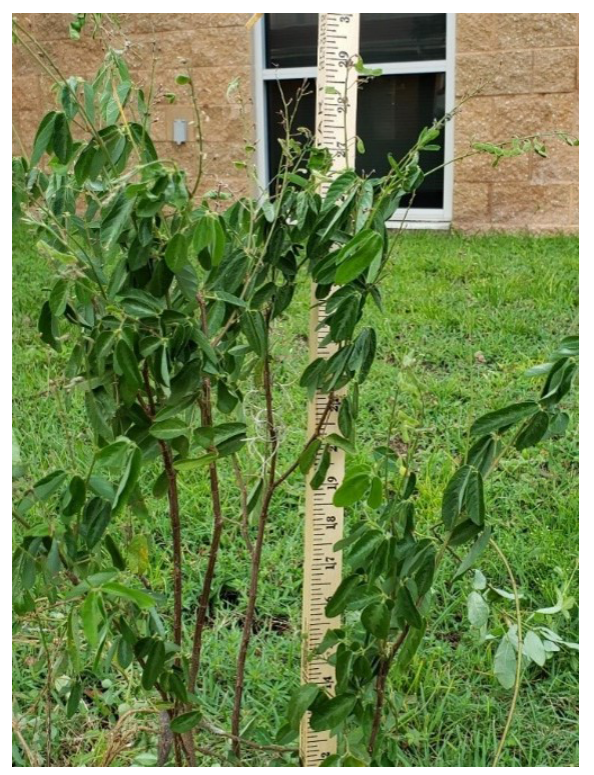

Figure 8. Creeping beggarweed growth habit. Credits: Grantly Ricketts, UF/IFAS 


\section{Management}

\section{Physical and Cultural Control}

Creeping beggarweed is very common in Bahiagrass, which is often because sod can be harvested from pastures with little to no weed-control program in place. For a new lawn, installing clean sod is the key to preventing creeping beggarweed. If a lawn is infested with creeping beggarweed, mow the lawn frequently to prevent plants from flowering and producing seeds that can be dispersed in the lawn. Creeping beggarweed can propagate vegetatively; therefore, a mower can spread parts of the stolons that can eventually become a new plant. Mow and bag clippings with weed seeds. For small areas that are not heavily infested, hand-weeding can be effective, but complete removal of the roots is required for effective control (Dalle and de Blois 2006). Tillage can be effective in agricultural production but is usually not feasible in the landscape. Following recommended guidelines for turf management, including proper irrigation, fertilization, and mowing, can help keep turf healthy and dense so that it is able to outcompete creeping beggarweed and other weed species. Recommended guidelines for turf management in Florida can be found here: https://edis.ifas.ufl.edu/ topic_book_florida_lawn_handbook_3rd_ed.

\section{Chemical Control}

There are two chemical control approaches to weed management: preemergence and postemergence herbicides. Preemergence herbicides work by killing weeds as they germinate and emerge from the soil. Postemergence herbicides kill weeds after they have been established. Using preemergence herbicides is often the favored approach because weed prevention is usually more effective and economical than managing established weeds. Additionally, there are usually more preemergence options for use in turf or planting beds compared with effective postemergence herbicides that are also safe for use on turf or in and around ornamental plants.

\section{PREEMERGENCE HERBICIDES}

Efficacy data are lacking for creeping beggarweed, although several preemergence herbicides are labeled for control or suppression of other Desmodium species such as Florida beggarweed, including dimethenamid-P (Tower) and flumioxazin (SureGuard). Dimethenamid-P could be used in all major warm-season turfgrasses in Florida and is also labeled for use in landscape planting beds. However, flumioxazin is only labeled for use in planting beds and must be used as a directed application, avoiding plant stems and leaves. Granular formulations of dimethenamid-P
(FreeHand, which also includes pendimethalin as an active ingredient) and flumioxazin (Broadstar) are also available and can be used in planting beds as well.

\section{POSTEMERGENCE HERBICIDES}

Like most weeds, creeping beggarweed will be most susceptible to herbicides during the immature stage of growth when most of the basal leaves emerge and before the bud breaks.

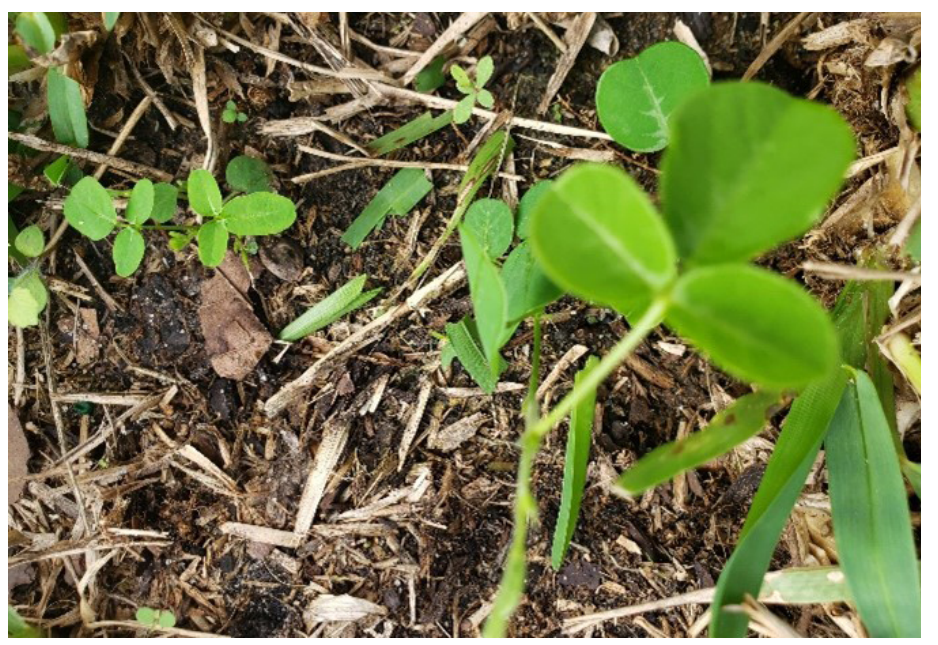

Figure 9. Immature creeping beggarweed.

Credits: Grantly Ricketts, UF/IFAS

In turfgrass, repeated applications of Group 4 herbicides are needed to control beggarweed (Patrick McCullough, University of Georgia). 2,4-D combination herbicides such as those that contain 2,4-D, dicamba, mecoprop-p acid (MCPP), or other general broadleaf herbicides (such as Trimec) have been reported to provide control of immature creeping beggarweed. Specific products would include SpeedZone ${ }^{\circledR}$ herbicide (2,4-D + dicamba+ mecoprop-p acid [MCPP] + carfentrazone) and Avenue South (penoxsulam + sulfentrazone $+2,4-\mathrm{D}+$ dicamba), among many others. Confront, which contains a mixture of triclopyr and clopyralid, provides good control for creeping beggarweed. Other herbicides such as those containing metsulfuronmethyl (Manson) or metsulfuron-methyl + sulfentrazone (Blindside) have proven to be effective. Depending upon weed size, a repeat application may be required to give good control on more mature plants. Note that herbicides containing 2,4-D may injure St. Augustine grass lawns under certain environmental conditions. Read the herbicide label to ensure that the turf species to be treated is listed as safe on the label.

In landscape planting beds, an herbicide such as glyphosate (many trade names) could be used on more mature plants and still achieve satisfactory control because it is a systemic and translocated herbicide. Contact herbicides, such as 
glufosinate (Finale), diquat (Reward) and pelargonic acid (Scythe), may also provide control of smaller plants (4 to 6 inches in height).

\section{Disclaimer}

Mention of a commercial or herbicide brand name or chemical does not constitute a recommendation or warranty of the product by the authors or UF/IFAS, nor does it imply its approval to the exclusion of other products that may also be suitable. Products should be used according to label instructions, and safety equipment required on the label and by federal or state law should be employed. Pesticide registrations may change, so it is the responsibility of the user to ascertain if a pesticide is registered by the appropriate state and federal agencies for its intended use.

\section{References}

Acevedo-Rodriguez, P. 2005. Vines and Climbing Plants of Puerto Rico and the Virgin Islands. Contributions from the U.S. Herbarium 51. 443 p.

Dalle, S. P., and S. de Blois. 2006. "Shorter Fallow Cycles Affect the Availability of Non-crop Plant Resources in a Shifting Cultivation System." Ecology and Society 11:2.

Etcheverry, A. V., M. M. Aleman, T. F. Fleming, C. A. Gomez, and S. D. Lopez. 2010. "Anther-stigma Separation in Desmodium Species (Papilionoideae-Fabaceae) from Northwestern Argentina." Acta Horticulturae 918:183-188.

Freitas, F. C. L., L. R. Ferreira, A. A. Silva, J. G. Barbosa, G. V. Miranda, and A. F. L. Machado. 2003. "Eficiencia do triclopyr no controle de plantas daninhas em gramado (Paspalum notatum).” Planta Daninha 21:159-164.

Green, S. E., K. A. Bradley, G. D. Gann, and C. Shulz. 2008. "Restoration of Privately Owned Rockland Habitat in Miami-Dade County." http://regionalconservation.org/ircs/ pdf/publications/2008_2.pdf. Accessed 1 Oct. 2020.

Mori, S. A., and J. L. Brown. 1998. "Epizoochorous Dispersal by Barbs, Hooks, and Spines in a Lowland Moist Forest in Central French Guiana." Brittonia 50:165-173.

USDA, NRCS. 2019. The PLANTS Database. National Plant Data Team, Greensboro, NC http://plants.usda.gov. Accessed 1 Oct. 2019.
Vendramini, J., and A. E. Kretschmer, Jr. 2016. Florida Carpon Desmodium. SS-AGR-112. Gainesville: University of Florida Institute of Food and Agricultural Sciences. https://edis.ifas.ufl.edu/ag249

Wunderlin, R. P., B. F. Hansen, A. R. Franck, and F. B. Essig. 2019. Atlas of Florida Plants. http://florida.plantatlas.usf. edu/. Accessed 1 Oct. 2019.

Younge, O. R., D. L. Plucknett, and P. P. Rotar. 1964. Culture and Yield Performance of Desmodium intortum and $\mathrm{D}$. canum in Hawaii. Technical Bulletin 59. Honolulu: University of Hawaii College of Tropical Agriculture, Hawaii Agricultural Experiment Station. 
Table 1. Herbicides labeled for suppression or control of Desmodium spp. Weed Specialist: Chris Marble PhD, UF/IFAS Mid-Florida REC/Horticulture
Active ingredient(s)
Example trade name
\begin{tabular}{l|l} 
MOA $^{1}$ & Timing $^{2}$
\end{tabular}
Turfgrass species $^{3}$
Turfgrass
Planting sites $^{4}$
beds $^{5}$

This table lists registered pesticides that should be integrated with other pest management methods. Additional information on integrated pest management methods can be requested from UF/IFAS Extension horticulture or agriculture Extension agents. A list of local UF/IFAS Extension county offices is at available at https://ifas.ufl.edu/.

\begin{tabular}{|c|c|c|c|c|c|c|}
\hline dimethenamid-P & Tower $^{\circledast}$ & 15 & PRE & $B A, B, C, S A, Z$ & Com, Res & OTT \\
\hline flumioxazin & SureGuard ${ }^{\circledR}$ & 14 & PRE & $B^{*}$ & Com, Res & Directed \\
\hline $\begin{array}{l}\text { Thiencarbazone-methyl + iodosulfuron + } \\
\text { dicamba }\end{array}$ & Celsius $^{\circledast}$ & $2+4$ & POST & $S A, C, Z, B$ & Com, Res & Not labeled \\
\hline $\begin{array}{l}\text { 2,4-D + dicamba + penoxsulam + } \\
\text { sulfentrazone }\end{array}$ & Avenue South ${ }^{\circledast}$ & $2+4+14$ & POST & $\mathrm{Z}, \mathrm{B}, \mathrm{C}$ & Com, Res & Not labeled \\
\hline Carfentrazone + 2,4-D + mecoprop + dicamba & Speed Zone ${ }^{\circledast}$ & $4+14$ & POST & $B, Z$ & Com, Res & Not labeled \\
\hline $\begin{array}{l}\text { 2,4-D + dichlorprop- } \mathrm{p}+\text { dicamba }+ \\
\text { carfentrazone }\end{array}$ & Speed Zone ${ }^{\circledast}$ Southern & $4+14$ & POST & $\mathrm{Z}, \mathrm{B}, \mathrm{BA}, \mathrm{C}$ & Res & Not labeled \\
\hline metsulfuron-methyl & Manor $^{\circledR}$ & 2 & POST & $S A, B, C$ & Res, Com & Not labeled \\
\hline triclopyr + clopyralid & Confront $^{\circledR}$ & 4 & POST & $B A, B, C, Z$ & Com & Not labeled \\
\hline sulfentrazone + metsulfuron & Blindside $^{\circledast}$ & $2+4$ & POST & $\mathrm{B}, \mathrm{C}, \mathrm{SA}, \mathrm{Z}$ & Com, Res & Not labeled \\
\hline sulfentrazone & Dismiss $^{\circledast}$ & 4 & POST & $\mathrm{BA}, \mathrm{B}, \mathrm{C}, \mathrm{SA}, \mathrm{Z}$ & Com, Res & Directed \\
\hline glyphosate & RoundUp ${ }^{\oplus}$ Pro & 9 & POST & Not labeled & Not labeled & Directed \\
\hline
\end{tabular}

${ }^{1}$ Herbicide groups are based according to primary sites of action and can be used to select herbicides that have differing sites of action (Weed Technology 17:605-619 [2003]) to minimize the potential for the development of herbicide-resistant weeds.

${ }^{2} \mathrm{PRE}=$ preemergence and POST $=$ postemergence .

${ }^{3} \mathrm{BA}=$ Bahiagrass, $\mathrm{B}=$ bermudagrass, $\mathrm{C}=$ centipede grass, $\mathrm{SA}=$ St. Augustine, $\mathrm{Z}=$ zoysia. Applicators should reference specific product labels to ensure the cultivar or improved variety of turfgrass is labeled for each turfgrass type. *Flumioxazin only labeled for use on dormant bermudagrass.

${ }^{4} \mathrm{C}=$ commercial or nonresidential turfgrass, $\mathrm{R}=$ residential.

${ }^{5}$ OTT = over-the-top applications are permitted on labeled plant species. "Directed" means herbicides can be applied, but spray must not contact any part of nontarget ornamental plants. "Not labeled" indicates herbicides that cannot be applied in landscape planting beds. 